\title{
The effects of dipeptidase inhibitor on peptide breakdown and VFA concentrations in rumen of sheep*
}

\author{
N.F. Zhang', Z.H. Wang ${ }^{1,3}$, F.C. Li ${ }^{1}$ and Q.Y. Diao ${ }^{2}$ \\ ${ }^{1}$ College of Animal Science, Shandong Agricultural University \\ No. 61 Daizong Street, Taian 271018, P.R. China \\ ${ }^{2}$ Feed Research Institute, Chinese Academy of Agricultural Sciences \\ No. 12 Zhongguancun South Street, Haidian, Beijing 100081, P.R. China
}

\begin{abstract}
The objectives of this study were to examine the effect of dipeptidase inhibitor (DI) on the concentration of $\mathrm{NH}_{3}-\mathrm{N}$, VFA and peptide $\mathrm{N}$ in rumen. Four Small-Tailed Han rams fitted with rumen fistula were fed with pelleted diets containing DI of different concentrations at four ten-days' experimental periods, respectively. Rumen fluids were taken through the fistula at last two days of each period. The results indicated that DI inhibited the release of $\mathrm{NH}_{3}-\mathrm{N}$ severely $(\mathrm{P}<0.05)$. In addition, the peptide $\mathrm{N}$ concentration increased $(\mathrm{P}<0.05)$ with the increase of DI concentration. However, the VFA concentrations, except propionic acid, were not affected.
\end{abstract}

KEY WORDS: dipeptidase inhibitor, dipeptide, $\mathrm{NH}_{3}-\mathrm{N}$, VFA, peptide $\mathrm{N}$, sheep

\section{INTRODUCTION}

Excessive breakdown of protein to ammonia in the rumen leads to inefficient utilization of dietary protein by ruminants, because much of the ammonia released is lost from the fermentation by diffusion across the rumen wall (Leng and Nolan, 1984). It would be beneficial to the nutrition of the animal by inhibited the degradation process at any of the degradation steps, such as proteolysis, peptide hydrolysis or amino acid breakdown (Witt et al., 1998). Peptides are intermediates in the catabolic process and therefore it might be possible to regulate ammonia production through inhibiting the breakdown of peptides (Wallace, 1996). The breakdown of peptides

\footnotetext{
* Supported by the Foundation of Key Technologies R\&D Programs, No. 96-003-03-02

${ }^{3}$ Corresponding author: e-mail: zhwang@sdau.edu.cn
} 
in the rumen appears to be a two-stage process, whereby oligopeptides are broken down mainly by dipeptidyl peptidases, and the dipeptides released are hydrolysed by separate dipeptidases (Wallace et al., 1993). Many different rumen microorganisms possess dipeptidase activity, Prevotella ruminicola is one of the most active bacteria in the breakdown of proteins and peptides in the rumen (McKain et al., 1992). It is also one of the numerous species, which plays a prominent role in each of the steps in the generation of ammonia from protein, sometimes comprising $>60 \%$ of the total bacterial population (Van Gylswyk, 1990). The dipeptidase activity of Prevotella ruminicola was found to be extremely sensitive to the metalloprotease inhibitor, 1,10-phenanthroline (Wallace et al., 1995). The aim of the present study was to examine the effects 1,10-phenanthroline, a dipeptidase inhibitor (DI), on peptide breakdown and VFA concentrations in the rumen fluids of sheep.

\section{MATERIAL AND METHODS}

\section{Animals and feeding}

Four castrated Small-Tailed Han rams with a mean BW of $36.08 \pm 1.75 \mathrm{~kg}$ were used. All the sheep were fitted with permanent rumen fistula (i.d., $55 \mathrm{~mm}$, wall thickness, $2.5 \mathrm{~mm}$ ), which were made of silicon rubber. The sheep were allowed to recover for two weeks prior to commencement of the study and then were placed in the metabolism crates. Animals were fed $1.1 \mathrm{~kg} / \mathrm{d}$ pelletted diet with auto-feeder at $1 \mathrm{~h}$ intervals, and allowed free access to water.

\section{Experimental diet}

The diet was formulated based on the feeding standard of meat-producing sheep and goats (NY/T 816-2004). Diet composition and the nutrient level were showed in the Table 1.

Table 1. Composition and nutrient level of the experimental diet

\begin{tabular}{lrlr}
\hline Ingredients, as feed basis, \% & & Nutrient level, g/kg \\
\hline Peanut stalk & 60.00 & Crude protein & 136.40 \\
Maize & 23.50 & Ether extract & 24.50 \\
Wheat bran & 5.00 & Crude fibre & 192.60 \\
Soyabean meal & 10.00 & Ash & 59.10 \\
Salt & 0.50 & Calcium & 15.40 \\
Premix $^{1}$ & 1.00 & Phosphorus & 6.10 \\
& & DE, MJ/kg & 11.08 \\
\hline
\end{tabular}

\footnotetext{
${ }^{1}$ Premix is a commercial product (Beijing Precision Animal Nutrition Research Centre, China) contains, mg/kg: Cu 800, Zn 6000, Fe 6000, Mn 6000, I 80, Se 20, Co 40, Mg 2000; IU/kg: vit. E 2000 , vit. A 900000 , vit. $\mathrm{D}_{3} 200000$
} 


\section{Experimental design}

The dipeptase inhibitor (DI) was added into pellets with the concentration of $0,0.8,1.0$ and $1.2 \mathrm{~g} / \mathrm{kg}$, respectively. The experiment was composed of four ten-day's periods. The adaptation of each period was 8 days, then the last 2 days were sampling period in which $50 \mathrm{ml}$ rumen fluid samples were collected at $4 \mathrm{~h}$ intervals. All the samples were stocked under $-20^{\circ} \mathrm{C}$.

\section{Analysis of samples}

Samples of rumen fluid were processed and analysed for volatile fatty acid (VFA), ammonia and the peptide concentrations. Ammonia nitrogen $\left(\mathrm{NH}_{3}-\mathrm{N}\right)$ was analysed by colorimetry as described by Chaney and Marbach (1962). Samples for VFA analysis were prepared as described by Jouany (1982) and analysed by gas chromatography. The peptide nitrogen of rumen fluids was estimated by the method described by Chen et al. (1987).

\section{Statistical analysis}

Data were analysed by the one-way analysis of variance procedure of SAS (1999). The means compared with the method of Duncan's multiple-range test, and the significance level was 0.05 .

\section{RESULTS}

The DI had significant effect on the production of $\mathrm{NH}_{3}-\mathrm{N}$ in rumen fluid (Table 2). The $\mathrm{NH}_{3}-\mathrm{N}$ concentrations of all experimental groups were lower than that of the control group. Especially, the $\mathrm{NH}_{3}-\mathrm{N}$ of group containing $1.0 \mathrm{~g} / \mathrm{kg}$ DI was significantly decreased $50.27 \%(\mathrm{P}<0.05)$ compared with that of the control group, but no significance were found with the group of containing $1.2 \mathrm{~g} / \mathrm{kg}$ DI. The results indicated that DI could inhibit the release of $\mathrm{NH}_{3}-\mathrm{N}$ at a certain concentration.

Table 2. Effects of DI on the concentrations of $\mathrm{NH}_{3}-\mathrm{N}$ and peptide $\mathrm{N}$ in rumen fluids

\begin{tabular}{lrrrr}
\hline DI concentration, g/kg & \multicolumn{1}{c}{0} & \multicolumn{1}{c}{0.8} & \multicolumn{1}{c}{1.0} & 1.2 \\
\hline $\mathrm{NH}_{3}-\mathrm{N}, \mathrm{mg} / 100 \mathrm{ml}$ & $33.66 \pm 6.06^{\mathrm{a}}$ & $25.49 \pm 1.94^{\mathrm{a}}$ & $16.74 \pm 3.82^{\mathrm{b}}$ & $18.97 \pm 7.22^{\mathrm{ab}}$ \\
Peptide N, g/l & $0.33 \pm 0.12^{\mathrm{a}}$ & $0.62 \pm 0.29^{\mathrm{ab}}$ & $0.68 \pm 0.14^{\mathrm{b}}$ & $1.70 \pm 0.07^{\mathrm{c}}$ \\
\hline
\end{tabular}

abc results are means of estimations carried out on samples taken from three sheep. Means with different superscripts within lines are significantly different $(\mathrm{P}<0.05)$ 
DI had significant effect on the peptide $\mathrm{N}$ concentration of rumen fluid (Table 2). The peptide $\mathrm{N}$ concentration increased significantly as the increasing of DI concentration compared with the control group. The concentration of peptide $\mathrm{N}$ of all experimental groups increased by $87.88,106.06(\mathrm{P}<0.05)$ and $415.1 \%$ $(\mathrm{P}<0.05)$, respectively.

The concentration of VFA except propionic acid had no significant changes between different groups (Table 3 ). The propionic acid concentrations of groups containing 0.8 and $1.2 \mathrm{~g} / \mathrm{kg}$ DI were significantly declined compared with the control group $(\mathrm{P}<0.05)$. The molar proportion of acetic acid of group containing $1.2 \mathrm{~g} / \mathrm{kg}$ DI was significantly higher $(\mathrm{P}<0.05)$, but the propionic acid was lower than in the control group. The rate of $\mathrm{C}_{2} / \mathrm{C}_{3}$ of all experimental groups were higher than that of the control group, and the group of adding $1.2 \mathrm{~g} / \mathrm{kg}$ DI had the highest rate $(\mathrm{P}<0.05)$.

Table 3. Effect of DI on the concentration of VFA in rumen fluids

\begin{tabular}{lcccc}
\hline Item & 0 & 0.8 & 1.0 & 1.2 \\
\hline Concentration of VFA, & mmol/l & & & \\
total VFA & $132.80 \pm 28.56$ & $123.70 \pm 28.67$ & $132.85 \pm 19.20$ & $130.48 \pm 25.24$ \\
acetic acid & $92.26 \pm 19.39$ & $91.02 \pm 23.32$ & $94.05 \pm 19.37$ & $97.46 \pm 20.81$ \\
propionic acid & $24.55 \pm 5.65^{\mathrm{a}}$ & $17.81 \pm 3.95^{\mathrm{bc}}$ & $21.14 \pm 3.26^{\mathrm{ab}}$ & $15.99 \pm 3.18^{\mathrm{c}}$ \\
butyric acid & $15.99 \pm 4.40$ & $14.87 \pm 3.24$ & $17.67 \pm 1.51$ & $17.03 \pm 2.41$ \\
& & & & \\
Molar proportion, $\%$ & & & & \\
acetic acid & $69.56 \pm 1.67^{\mathrm{b}}$ & $73.02 \pm 4.62^{\mathrm{ab}}$ & $70.25 \pm 5.67^{\mathrm{ab}}$ & $74.42 \pm 2.50^{\mathrm{a}}$ \\
propionic acid & $18.47 \pm 1.17^{\mathrm{a}}$ & $14.63 \pm 2.32^{\mathrm{bc}}$ & $16.15 \pm 3.09^{\mathrm{ab}}$ & $12.39 \pm 2.10^{\mathrm{c}}$ \\
butyric acid & $11.98 \pm 1.70$ & $12.35 \pm 2.87$ & $13.61 \pm 2.87$ & $13.20 \pm 1.26$ \\
$\left(\mathrm{C}_{2}+\mathrm{C}_{4}\right) / \mathrm{C}_{3}$ & $4.44 \pm 0.37^{\mathrm{c}}$ & $5.97 \pm 1.02^{\mathrm{ab}}$ & $5.39 \pm 1.27^{\mathrm{bc}}$ & $7.22 \pm 1.15^{\mathrm{a}}$ \\
$\mathrm{C}_{2} / \mathrm{C}_{3}$ & $3.78 \pm 0.30^{\mathrm{c}}$ & $5.13 \pm 1.00^{\mathrm{ab}}$ & $4.54 \pm 1.23^{\mathrm{bc}}$ & $6.14 \pm 1.00^{\mathrm{a}}$ \\
\hline
\end{tabular}

abc means with different superscripts within lines are significantly different $(\mathrm{P}<0.05)$

\section{DISCUSSION}

The activities of the main rumen bacterial species with high dipeptidase activity, Prevotella ruminicola, was inhibited $95.17 \%$ by 1,10 -phenanthriline (Wallace et al., 1996). When trypticase, a pancreatic casein hydrolysate containing a mixture of oligopeptides, dipeptides and amino acids, was incubated with rumen fluid, the production of ammonia and free amino groups was inhibited about $71 \%$ by 1,10-phenanthroline (Wallace et al., 1996). Zhang et al. (2003) estimated the influence of 1,10-phenanthroline concentrations on in vitro fermentation of mixed ruminal microorganisms, the result indicated that 1,10-phenanthroline inhibited gas production and $\mathrm{NH}_{3}-\mathrm{N}$ concentration severely. In the present experiment, $\mathrm{NH}_{3}-\mathrm{N}$, VFA and peptide nitrogen concentration in the rumen were measured when different 
amount of DI were supplemented into diets. The concentration of ammonia, which were products of amino acid breakdown, was lower than the control group, the results of present experiment also indicated that DI inhibited the release of ammonia nitrogen, and the $1.0 \mathrm{~g} / \mathrm{kg}$ DI group had the lowest $\mathrm{NH}_{3}-\mathrm{N}$ concentration. There were possibilities that the lowered rumen $\mathrm{NH}_{3}-\mathrm{N}$ by DI supplementation may have adverse impact on rumen bacteria growth as some previous studies reveled that $\mathrm{NH}_{3}-\mathrm{N}$ was necessary for efficient rumen bacteria growth. Schaefer et al. (1980) reported that the optimal rumen $\mathrm{NH}_{3}-\mathrm{N}$ concentration for rumen microbial growth was $1.4 \mathrm{mg} / 100 \mathrm{ml}$, and the result of Satter and Slyter (1974) was $5.0 \mathrm{mg} / 100 \mathrm{ml}$. However, Mehrez et al. (1977) reported that the optimal rumen $\mathrm{NH}_{3}-\mathrm{N}$ concentration to reach the optimal degradation of the DM of barley by dacron bags method was $19.4 \mathrm{mg} / 100 \mathrm{ml}$. The lowest rumen $\mathrm{NH}_{3}-\mathrm{N}$ concentration $(16.74 \mathrm{mg} / 100 \mathrm{ml})$ was observed when $1.0 \mathrm{~g} / \mathrm{kg}$ DI was supplemented in the present study. It was slightly lower than the recommendation of Mehrez et al. (1977), but higher than the results of Satter and Slyter (1974) and Schaefer et al. (1980), so DI supplementation may behave no significant influence on rumen bacteria growth in the present study. Correspondingly, the peptide $\mathrm{N}$ showed significant increase, which indicated apparently that DI inhibited the breakdown of peptide. Therefore, DI inhibited the breakdown of peptides and the dipeptidase actives of rumen microorganisms, and could be used as a means of controlling ammonia production from peptides in the rumen.

In present experiment, with the adding of DI, the propionic acid concentration decreased, it maybe related to the decrease of ammonia that was the substrate of some kinds of starch digestive bacteria, such us Ruminobacter amylophilus and Prevotella ruminicola, and these bacteria was mainly responsible for the produce of propionic acid in rumen. Moreover, the further research was needed to obtain the exact mechanism.

\section{CONCLUSIONS}

It was concluded that dipeptidase inhibitor(DI) inhibited the release of ammonia from peptide and improved the production of peptides in rumen with the increase of DI. When DI concentration was higher than $1.0 \mathrm{~g} / \mathrm{kg}$ in diet, the effect of DI in controlling the breakdown of peptide was effective. The VFA concentrations, except the propionic acid that was decreased, were not affected.

\section{REFERENCES}

Chaney A.L., Marbach E.P., 1962. Modified reagents for determination of urea and ammonia. Clin. Chem. 8,130-132 
Chen G., Russell J.B., Sniffen C.J., 1987. A procedure for measuring peptides in rumen fluid and evidence that peptide uptake can be a rate-limiting step in ruminal protein degradation. J. Dairy Sci. 70, 1211-1219

Jouany J.P., 1982. Volatile fatty acids and alcohol determination in digestive contents, silage juice, bacterial cultures and anaerobic fermentor contents. Sci. Aliment. 2, 131-144

Leng R.A., Nolan J.V., 1984. Nitrogen metabolism in the rumen. J. Dairy Sci. 67, 1072-89

McKain N., Wallace R.J., Watt N.D., 1992. Selective isolation of bacteria with dipeptidyl aminopeptidase type activity from the sheep rumen. FEMS Microbiol. Lett. 95, 169-174

Mehrez A.Z., Ørskov E.R., McDonald I., 1977. Rates of rumen fermentation in relation to ammonia concentration. Brit. J. Nutr. 38, 437-443

NY/T 816-2004. Feeding Standard of Meat-Producing of Sheep and Goats

SAS, 1999. Statistical Analysis System. User's Guide: Statistics, Version 8.2 Edition. SAS Institute Inc. Cary, NC

Satter L.D., Slyter L.L., 1974. Effect of ammonia concentration of rumen microbial protein production in vitro. Brit. J. Nutr. 32, 199-208

Schaefer D.M., Davis C.L., Bryant M.P., 1980. Ammonia saturation constant s for predominant species of rumen bacteria. J. Dairy Sci. 63, 1248-1263

Van Gylswyk N.O., 1990. Enumeration and presumptive identification of some functional groups of bacteria in the rumen of dairy cows fed grass silage-based diets. FEMS Microbiol. Ecol. 73, 243-254

Wallace R.J., 1996. Ruminal microbial metabolism of peptides and amino acids. J. Nutr. 126, 13261334

Wallace R.J., Frumholtz P.P., Walker N.D., 1993. Breakdown of N-terminally modified peptides and an isopeptide by rumen microorganisms. Appl. Environ. Microbiol. 59, 3147-3149

Wallace R.J., Kopecny J., Broderick G.A., Walker N.D., Sichao L., Newbold C.J., McKain N., 1995. Cleavage of di- and tripeptides by Prevotella ruminicola. Anaerobe 1, 335-343

Wallace R.J., Newbold C.J., McKain N., 1996. Inhibition by 1,10-phenanthroline of the breakdown of peptides by rumen bacteria and protozoa. J. Appl. Bacteriol. 80, 425-430

Witt M.W., Newbold C.J., Wallace R.J., 1998. Influence of dietary acetylated peptides on fermentation and peptidase activities in the sheep rumen. J. Appl. Microbiol. 84, 847-851

Zhang N.F., Wang Z.H., Li B., Gao X.H., 2003. The influence of 1,10-phenanthroline concentrations on in vitro fermentation of mixed ruminal microorganisms. Chin. J. Anim. Nutr. 15, 28-31 